tame and impudent, allowing a very near approach, and when closely pursued retiring but a short distance. Like some species of gull, this bird is in the habit of carrying clams high in the air and then dropping them, in order to break the shell. Dr. Studley says: "In watching one thus employed I was very much amused at the unsuccessful endeavours he made to break the shell of a clam by letting it drop upon soft ground. He continued for a long time carrying and recarrying the same clam high aloft and fruitlessly dropping it on the prairie sod. He nevertheless persisted in his efforts until I became tired of watching him. What the result was I am unable to state."

\section{THE BRITISH ASSOCIATION MEETING AT EDINBURGH}

\section{EDIN BURGH, Wednesday Morning}

$7 \mathrm{HE}$ proceedings of this year's meeting are now rapidly 1 drawing to a close, so near, in fact, is the end, and so apparertly far back in time is the beginning, that already it is easy to sum up the results, and to get a general view of the meeting in its various aspects.

The meeting has certainly been in every respect a most successful one; the weather has done all in its power to conduce to the enjoyment of the members, and to belie the southern notions as to climate. First, as to the attendance: The numbers attending the former meetings here have been almost, if not quite, doubled, and, in fact, we may assume that they bave been much larger than was expected, otherwise another, though in some respects a less convenient arrangement for the sectional work would have been adopted. As it is, we have had all the sections massed in the University in the various classrooms - an arrangement which reduces the necessary loco. motion to a minimum, and gives the greatest facility to those who choose to visit all the sections, affording a striking contrast to the great waste of time and other inconveniences which resulted from the disconnected positions of some of the sections at Liverpool. The drawback is, that the numbers being so large, the small classrooms have quite broken down in the matter of accommodation, and ingress and egress have been almost im. possible.

But in British Association Meetings, as in other things, numbers alone must not be too much considered; and this leads us to the wonderful galaxy of physicists who apparently have come to Edinturgh to do konour to the President. The briliiancy of the gathering, both of British and Foreign men of science in the mathematical and physical section, has been the subject of general remark, and we refer to it, not at the expense of the other sections, but as an indication of what has happened there also, though not to such an extraordinary degree. Joule and Colding, Cayley and Sylvester, Thomson and Tait, Janssen ar:d Huggins, Clifford and Spottiswoode, are combinations not to be seen every day, and the extreme interest of the discussions carried on under such conditions may be easily imagined, much more easily imagined, indeed, than described. Prof. Zenger, of Bohemia; Dr. Paul Güssenfeldt, of the Univєrsity of Bonn; Prof. Van Beneden, of Louvain; E. L. Youmans, of New York; Rev. J. R. Loomis, LL.D., President of University of Lewisburg, U.S. ; Prof. Dr. E. H. von Baumhauer, Secretary of the Dutch Society of Science, Haarlem; Dr. C. H. D. Buys Ballot, of Utrecht ; C. Gilbert Wheeler, Professor of Chemistry at the University of Chicago; Dr. Baron R. Eötvös, Professor of Mathematics and Physics at the University of Pesth; Dr. D. Bierens de Haan, Professor of Mathematics, Leiden; are among the foreigners who have attended the meetings in addition to those alluded to last week; not to mention the names of many distinguished
English and Scotch savans, who attend as representatives of various scientific bodies in different parts of the country. Then as to the number of papers presented. With the exception of the Mechanical Section, presided over by Prof. Jenkin, the supply of papers has been superabundant. with a quality above the average. So numerous have been the papers in some sections, that divisions have been formed to enable them to be get through.

As to the local conditions of success, we need only say that the meeting is in one of the most beautiful cities of the world, the society of which takes its tone from a wide diffusion of intellectual culture, and where hospitality takes no refusal, and just escapes killing by kindness.

This meeting may be said to have really commenced on the day before the meeting of the General Committee, and of the delivery of the President's address, in consequence of the attendance of so many men of science at the graduation ceremonial of the University, to which we referred last week, when we gave the names of those who had the honorary degree of LL. D. conferred on them. We may here add that the recipients were introduced by Prof. Macpherson, the Dean of the Faculty of Law, in a way which greatly enhanced the value of the honour.

This ceremony was followed by the "capping" of ninety-six gentlemen who had just completed their studies. One of the secrets of Edinburgh's great success as a medical school appears to us to lie in the mode of bringing out originality among her students, which we would gladly see adopted in the science teaching of our English Universities. When a student takes the degree of M.D., he is required to write a thesis on some subject belonging to the sciences related to medicine. Gold medals are awarded for such theses as contain an amount of original work which is deemed worthy of the honour. The consequence of this is, that every year two or three, or even more, really good original memoirs are produced. These are, in very many instances, the nuclei of still greater things in after-life. Powers of research, which might otherwise have lain dormant, are brought out; and so at an early period of life, men get into the habit of doing original work. We are assured by Edinburgh men that the system is, as one would have expected, fraught with excellent results. Our wealthy English universities would do well to take a lesson from their poorer sister; and, instead of rewarding so highly mere grinding in science, they would do well to do something more to develop doers of original scientific work. On this occasion the gentleman who obtained the highest honours is Dr. Urban Pritchard.

This ceremony, after all, however, was merely the prelude. Prof. Bennett's graduation address was the first sensation of the meeting. Indeed, those who had come north with more acquaintance with Dean Ramsay's stories than with the present tone of thought, were simply astonished at the boldness with which Mr. Bennett handled subjects on which, it was imagined, any expression of opinions such as his would not be tolerated. Here, for instance, is a specimen :-

"At the congress of naturalists and medical men held at Innsbruck in 1869 , Helmho tz claimed for Germany the principal agency in the progress of modern science. She owes this superiority, he said, to the boldness of her savans in propagating truth, whilst, he asserted, that in England and France they dare not do so openly, for fear of compromising their social interests. But $I$ trust the time is past, even in Scotland, when scientific truth has anything to fear from superstitious bigotry or clerical intolerance. It is true that we are constantly hearing that there is a tendency to place new scientific doctrines in opposition to religious beliefs. But I would suggest that the cause of this is not that scientific men are irreligious, so much as that religious men are unscientific. It is utterly impossible, in these days, to oppose the most obvious facts, or persecute the great discoverers of the day, because the writers of the Old and New Testament, I, 800 or 3,000 
years ago, knew little of astronomy, chemistry, and physics. Such, however, has been the unfortunate policy of the Church for many centuries. I need not remind you that the great Galileo died a prisoner of the Inquisition, and that Servetus was publicly burnt in Geneva, by the authority of Calvin. The true cause, unquestionably, of the present chasm in thought which divides the literary and religious from scientific men is, that the former have been bred up in ignorance of physiology, that is, of all that relates to their own bodily structure, functions, and requirements. Unfortunately, their education causes in them a want of appreciation and an incapacity of comprehending scientific truths. . . . . Clergymen and most religious teachers are totally insensible to the errors and discrepancies of language they use in the pulpit; so that, when the scientific man takes his place in church, he is surprised at the manifest ignorance of established truths constantly preached to the people."

The main object of the lecture was to insist upon the fact that physiology in some form or other shosid constitute a part of the education of every one. A Committee of the British Association for the Advancement of Science strongly recommended it in 1868 ; and wherever it has been tried it has been attended with marked success, especially in girls' schools, and to illustrate this point $\mathrm{Mr}$. Bennett showed how, adding that "Perhaps women in all classes and degrees of society have more to do with the preservation and duration of human life even than men and in all ranks of society should have physiology taught them. It should be an essential subject in their primary, secondary, and higher schools. So strong are my convictions on this subject, that I esteem it a special duty to lecture on physiology to women, and whenever I have done so, have found them most attentive and interested in the subject, possessing indeed a peculiar aptitude for the study, and an instinctive feeling-whether as servants or mistresses, wives or mothers-that that science contains for them, more than any other, the elements of real and useful knowledge. In advocating the propriety, therefore, of introducing physiology as an essential part of education to all classes of society, I would observe in the last place, that when you enter upon the duties of your profession, you will find too frequently that your best efforts are frustrated by parents, nurses, or attendants on the sicls, who, not comprehending, are therefore incapable of carrying out your instructions. I have myself seen, only too frequently, the most melancholy deaths produced in families, and extreme wretchedness occasioned, from carelessness or ignorance of what ought to be donearising entirely from an unacquaintance with the most common rules requisite for the preservation of life."

It is a strange rider to this to add, that the University here has just by its vote rendered the higher education of women in these subjects impossible for the present so far as Edinburgh is concerned, though it is fair to remark that the majority was so narrow that it is not too much to hope that ere long this decision, which is eminently to be regretted, will be reversed.

At the meeting of the General Committee on Wednesday, the reports of the Council, in which they gave an account of their stewardships for the past year, and the report of the Kew Committee, were read. It is not necessary to give either of these documents in extenso, but the following references to them may be useful. The connection between the Association and Kew Observatory is to cease, and the Government is to be informed of the Association's desire to see its direction and maintenance transferred to the Royal Society, who will administer the means placed at the disposal of science by the munificence of Mr. Gassiot. Dr. Hirst has resigned his office as joint general secretary, and Mr. Douglas Galton, C.B., F.R.S., has been elected to succeed him. Those who know Mr. Galton will heartily congratulate the Association on his willingness to undertake the duty. Prof. Van Beneden, Dr. Crafts, Dr.
Anton Dohrn, Governor Gilpin, of Colorado, H.H. the Rajah of Kolapore, M. Plateau, and Prof. Tchebichef have been added to the list of corresponding members. The consideration of some revised regulations drawn up by the Council for regulating the proceedings of the several sections was postponed for a future meeting.

An important recommendation has been urged by the committees of the Biological and of the Geological sec. tions, which is likely-if accepted by the Council-to increase much the scientific value and interest of the meetings of the Association. It has been recommended that, in addition to the various rooms provided for the meetings of the sections, sale of tickets, \&c., a room be annually provided for the purposes of a temporary museum. It cannot be doubted that such a museum would be a great success. In the meetings of the British Medical Association and the Archæological Association similar museums are very important features of the proceedings. A good-sized room, provided with a number of glass-cases arranged on tables, such as are always to be hired in large towns, would constitute the machinery of the museum. One or two reliable members of the Association would have the management of it, and exclude un desirable or worthless objects, whilst whipping in all of special interest; members would bring new and rare geo. logical specimens, zoological specimens, human crania, flint-weapons, physiological apparatus, chemical apparatus, and microscopes, which would all be arranged judiciously and ticireted. We have no hesitation in saying that such a museum, when once brought into working order, would be the greatest attraction of the meeting. The proposal was originated by Mr. Ray Lankester.

Thanks to the exertions of Dr. King, who urged strongly the formation of a separate section for Ethnology, the meeting of the Committee was not altogether dull, and this gentleman, who is a born Irishman, if not an Irishman born, fairly convulsed the Committee by his method of appeal. First he urged that there should be a separate section, because the Queen and Prince Consort "had come in their yacht to visit all the sections" at the Southampton Meeting. Next he complained that at Exeter the ethnologists "were put into a room which would not hold them," but the appeal was unavailing, Prof. Huxley's quietus came in due time, and the matter-and Dr. King-dropped.

The definite acknowledgment of Anthropology as a department of the Biological Section of the British Asso. ciation, has led to the admission of a wide range of subjects in that department. "What is man?" is a question which cannot be answered by comparative anatomy alone. Dr. Tristram proposed in committee that Psychology be recognised as a distinct branch of Anthropology. This proposal was overruled by the declaration of the president, that man as a compound being could not be discussed apart from the psychological as pects of the question.

The Anthropological Department has, consequently, been flooded by papers of the most controversial tone on this side of the investigation of humanity. The most pro. vocative papers on the subject were those of Mr. Staniland Wake, on Man and the Ape, and of Mr. Kaines, on the Anthropology of Comte. Both these papers are vigorously attacked on the Psychological side; the opponents of Positivism taking their stand on the contemptuous rejec. tion of metaphysics by the writers. But the Positivist papers necessarily invoked the theological element, as they assumed at the outset that the whole metaphysical side of the question must be expunged, as being a question of which physicists were incompetent to judge. This led to as universal an affirmation of the tripartite nature of man, by various speakers, led by Mr. Boyd Dawiins, and the impossibility of admitting the premises of the writers on his origin until the origin of his spirit had been demonstrated to be material.

Among the topics of general conversation during the 
first part of the meeting, have been the proposed dredging exploration, which it is understood will be undertaken by the Government, following the example set by the American, Swedish, and other nations, and the proposed Eclipse Expedition to Ceylon next December. The former announcement has been hailed with the liveliest satisfaction; and the Government is on all hands congratulated on its appreciation of the importance of this work. The feeling touching the Eclipse Expedition is of an entirely opposite character, as it has leaked out that this year, as last, affairs have been delayed and badly managed. After Messrs. Lockyer's and Janssen's papers on 'Friday, Sir William Thomson said he joined very warmly in what Mr. Lockyer and M. Janssen had urged. M. Janssen had asked that Britain should join France and Germany in this friendly struggle, and it would be a disgrace to England if it did not accept that challenge, and do its very best to beat both France and Germany in the struggle, adding that all the efforts of all the nations would not be too much for the importance of the work. The Scotsman, in a leading article on this subject, after urging an appeal to Government on the part of the British Association, writes as follows :- -...

"The Chancellor of the Exchequer, in fact, who is de facto the keeper of the nation's purse, is de jure, so far as science is concerned, the keeper of the nation's honour; and may the time be long distant when the honour of England shall be tarnished by her relinquishing those expeditions and scientific explorations to the precursors of which we all look back with so much pride. Surely, from this point of view, it should be a subject of regret to the leaders of science now among us that the progress of the $n$ ation's best interests should be liable to be thwarted by the jealousies and self-seeking of individuals, and we are glad to learn that the action of the British Association, which we are informed becomes necessary in consequence of some such cause as this, is likely to be carried forward with such vigour that Her Majesty's Government will willingly yield to the demands of science, while at the same time a salutary lesson will be read to those who attempt to make the progress of science-the national importance of which is thoroughly acknowledged heresubservient to their own selfish interests. We have been the more anxious to make these remarks, because we think the time has arrived when the general interests of science and truth demand that any effort, by whomsoever made, to retard the progress of knowledge, should be publicly met without respect of persons and without hesitation; and we may express a hope that the Parliament of Science, now assembled in this city, will counteract the efforts of an oligarchy in the same bold manner as the Parliament of the nation has recently done." In these remarks we cordially concur.

We may dismiss this subject by stating that an application for aid is to be sent off to the Government to-night.

The President's address, delivered in the evening in the Music Hall, was received with enthusiasm. The Emperor of Brazil, who seems to have come over to this country to show how easily our own rulers might further the progress of science if they chose, occupied a seat on the platform, which was as crowded by the general committee as the body of the Hall was by the ordinary members. Prof. Huxley, in resigning the presidential chair to Sir William Thomson, reminded his auditors of the achievements of the new president, which in this age of cultivation of science and in the pressing rivalry of able and accomplished men in all directions, entitled him to the appellation of an "intellectual giant," adding, as the poet says of Lancelot,---

$$
\text { Gentler knight }
$$

There never broke a lance.

On the morrow the sectional work began in real earnest, and has continued with but small interruptions ever since -theinterruptions consisting in excursions on the Saturday, by which the geological, chemical, and botanical sections protested against that rule of the Council which attempts to discountenance such blandishments during the Association, forgetting, as it seems to us, the extreme value of local inquiries which it is impossible to carry out otherwise, as every moment is so fully occupied. Our notice of the sectional work may here be very brief, as we shall give in their proper places notices of all papers of importance or interest.

After the reading of the addresses, in Section A Dr. Carpenter made an interesting communication with reference to oceanic currents. Sir W. Thomson and Prof. Stokes joining in the discussion, which was followed by a paper by $M$. Janssen on his balloon experiences. Among the papers submitted to the Chemical Section the most popular was perhaps one relating to the working of hæmatite ore. The Geological Section had some papers of local interest, as also a report on Scotch e rrthquakes. Of the zoological papers, a report from the Close-Time Committee, and a paper on the rarer raptorial birds of Scotland, gave rise to a discussion on the extirpation of indigenous animals. This was followed by an important paper on co-operation among natural history societies. The Anthropologists discussed such subjects as longevity, and the degeneration of race in Britain; the Geographers received notes of researches in various parts of the world; and among the subjects taken up in the Economic Science Section was that of the Merchant Company's schools.

On Friday the proceedings in Section A were opened by papers by Mr. Lockyer and M. Janssen on the recent and coming eclipses. The Chemical Section had, among other papers, a report on recent progress in chemistry in the United States. The geologists received a report on the exploration of Kent's Cavern, besides papers detailing the results of researches in various departments of the science. The Anthropologists discussed, among other subjects, that of ancient hieroglyphic structures. In the Biological Department, spontaneous generation formed the subject of a small discussion between Dr. Calvert and Dr. Bastian, and an important paper was communicated by Prof. Thistleton Dyer on mimicry in plants. The geographical programme included papers on the geography of Moab and the famous Moabite stone. In the Economic Section a lively discussion took place on the Merchant Company's Education Scheme, introduced by Mr. Boyd's paper of the preceding day.

On Saturday, Monday, and yesterday, the flow of papers still continued, the Anthropological Section soon becoming notorious for actual or probable rows, though nothing very serious took place. The questions of state aid to science, and obstacles to science teaching in schools, were discussed yesterday in Section A, and here our notice must stop.

To-day we have the final General Meeting, and as many of the recommendations which have been made during the meeting will be discussed there, it will be well to delay our notice of them till next week, merely remarking here that we never knew a larger number of valuab!e recom. mendations made for action or money grants. In the meeting of the General Committee on Monday, Bradford was fixed upon as the next place of meeting after Brighton, with Belfast in reserve for the year after. The appointment of Dr. Carpenter as next president was moved in a highly eulogistic speech by Prof. Huxley; the officers of the Association were re-elected with the exception of Dr. Hirst, who, as before stated, is succeeded by Mr. Douglas Galton; and the following Council was appointed for the ensuing year: Messrs. Bateman, Beddoe, Debus, Fitch, G. C. Foster, M. Foster, F. Galton, Gassiot, R.A.C., Godwin-Austen, Huggins, Gwyn-Jeffreys, Lockyer, Merrifield, Ramsay, Simon, Tyndall, Wallace, Williamson, Sir Stafford Northcote, Sir Charles Wheatstone, Colonel Strange, Colonel Sykes, and General Strachey. 
The lectures and conversaziones have been great successes, the former we hope to be able to give at some length next week. We must not conclude this letter, written from Edinburgh- the den of the great "Red Lion" Forbes-without adding that the Red Lions dined together on Monday, Lion King Rankine occupying the chair.

The following papers were contributed to this section by unknown au hors:-

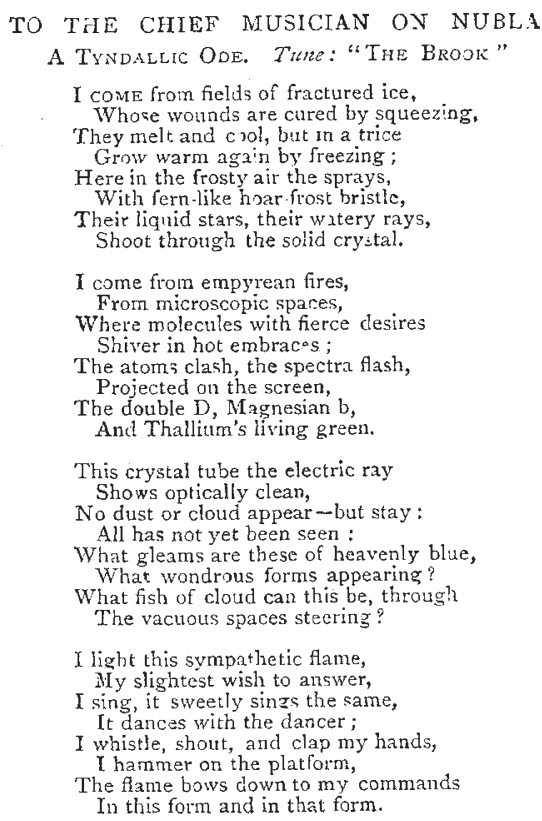

$I$ light this sympathetic flame,

My slightest wish to answer,

sing, it sweetly sings the same,

It dances with the dancer;

I whistle, shout, and clap my hands,

I hammer on the platform,

The fiame bows down to my commands

In this form and in that form.

THE BRITISH ASS

(Snng by $x$ Cub at the Red Lions' Feed, Eulinburgh, Aitgust 7, r871) Air: "The British Grenadiers"

Some men go in for Science, And some go in for Shans,

Some roar like hungry Lions,

And others bleat like Lambs;

But there's a Beast that at this' Feast

Demands a special glass, So let us bray, that long we may
Admire the British Ass! With a tow, row, row, \&c., \&c.

On England's frigrant clover

This Beast delights to browse,

But sometimes he's a rover

To Scotland's bromy knowes;

For there he finds above all kind

The Plant that doth surpass

The Thistle rude-the sweetest food

That feeds the British Ass!

We've read in ancient story

How a great Assyrian swell

Came down from all his glory

If you would know how it happened so,

That a King should feed on grass,

In Section D, Department B,

$\mathrm{He}$ had joined the British Ass

On Grecian senses charming

Fell the music of the spheres,

But voices more alarming

Salute our longer ear:.

A swell profound doth now propound

How life did come to pass,

From world to world the seeds were hurled,

Whence sprung the British Ass!

In our wandering through Creation We meet these burning stones,

That bring for propagation

The germs of flesh and bones.

And is it not a thrilling thought

And is it not a thrilling though

will come some day to sweep away

Our dear old British Ass!
The child who knows his father

Has aye been reckoned wise,

But some of us would rather

If it be true that wher we vi:w;

A comely lad or lass,

We find the trace of the monkey's tace

In the gaze of the British Ass!
In the

\section{SECTION A.}

Thursday, Aug. 3.- Speculations on the Continutity of the Fluid State of Matter, by Prof. James Thomson, of Belfast. The author proceeding from the researches of Dr. Andrews on the Continuity of the Liquid and Gaseous States of Matter, in which it has been discovered that there is gradual transition between the ordinary liquid and the ordinary gaseous states of the same matter by courses passing through temperatures and pressures above those at which boiling can take place, showed that there is probably also a theoretical continuity having a real and trne significance directly across temperatures and pressures of boiling points. This he showed by supposing there to be conditions partly stable and practically attainable, and partly unstable, corresponding to curved reflex junctions of the curves shown by Dr. Andrews for the gaseous and liquid states, ${ }^{*}$ where they are interrupted at the boiling breach of continuity. As these new views of Prof. Thomson form the subject of a paper submitted to the Royal Society and intended to appear in an early number of the Proceedings, we hope to give a fuller account of them in a future issue.-Prof. Thomson also drew the attention of the Section to the existence for each of the various substances, (water, or carbonic acid, for instance,) of a remarkable point of pressure and temperature, at which alone the substance can exist in three states, solid, liquil, and gaseous, together in contact with one another. This point of pressure and ternperature he designates as the triple point; and he shows how this point belongs to three important curves, as being their intersection. On this subject also we propose soon to give a fuller exposition of Prof. Thomson's views.

\section{SECTION B.}

ON Thursday, after the address of the President, Dr. Andrews, which has already appeared in our columns, Mr. Dewar presented his Report on Thermal Equivalents of the Oxides of Chlorine. The results were merely preliminary, and exhibited in a remarkable manner the difficulties attending this class of investigations. Dr. Gladstone followed with a paper, which he had prepared in conjunction with Mr. Alfred Tribe, On Some Experiments on Chemucal Dynamics. He commenced by referring to a paper recently communicated to the Royal Society, in which it was shown that in various decompositions of metallic solutions the chemical change, in a given time, is not in proportion to the amount of salt present, but that twice the quantity gives three times the chemical action, and also that whi!e silver is deposited in copper, in the decomposition of nitrate of silver by copper an actual passage of the nitric element towards the copper plate occurs.

In the present paper, the authors exhibited this latter phenomenon in a dissected form, with other observations. A copper plate was immersed in copper nitrate, and a silver plate in silver nitrate; : while the two metals were connected by a wire, and the liquids by a porous cell. Silver deposited upon the silver plate, and the copper plate dissolved; the sp. gr. of the copper nitrate increased from I $O I 5$ to $I^{\circ} 047$, and only a trace of this salt pássed into the cell which originally contained silver nitrate. The passage of $\mathrm{SO}_{4}\left(\mathrm{SO}_{4} \mathrm{H}_{2}\right.$ ?) was also found to take place by an analogous experiment.

Similar experiments were made in which the nitrate of silver was kept constant, but the nitrate of copper was increased in equivalent multiples. It was found that the silver deposited increased with the increase in copper salt, being about double when the copper salt was seven times as strong, and that the effect of successive additions gradually diminished. This is in strict accordance with other experiments showing that when the copper plate is immersed in a mixture of the nitrate of copper and silver, the amount of silver deposited is increased, though in a diminishing ratio, by successive additions of copper salt. That this acceleration is not produced by a copper salt only was proved by repeating the experiments with various other nitrates. The tabulated results show that the increased effect does not de-

* The reader vill find these curves engraved in NAturr for Angust 4, I 870 , p. 270 . 
pend simply upon the nitric element, but likewise on the nature of the salt.

In the discussion which followed, some curious facts were elicited with respect to the action of sugar on metallic iron. It is well known that hitherto it has rot been possible, on account of this action, to convey sugar in iron ships; but Dr. Calvert stated that he had discovered a very simple method, which entirely prevented the action, and he had no doubt that henceforward sugar would be as safely carried in iron ships as in wooden bottoms.

Mr. Thos. Ainsworth then read a paper On Facts Deceloped by the working of Hamatite Ores in the Ulverstone and Whitehaven districts from 1844-187r. The communication was exceedingly well illustrated by diagrams and specimens; but the conclusions arrived at by Mr. Ainsworth were pretty generally combated.

On Friday the proceedings commenced with a paper by Prof. Wheeler, of Chicago, On the Recent Progress of Chemistry in the United States. Mr. Henry Deacon gave an account of his Chlorine Process as applicd to the Manufacture of Bleaching Poider on the larger Scale. A note On Regianic Acid, a product derived from walnuts, was then communicated by Dr. Phipson. It was followed by a paper by Dr. Calvert On the Estimation of Sulphur in Coal and Coke. The sulphur found in coal or coke often exists in two states, partly as sulphuric acid combined with lime, and partly as sulphur combined with iron; it is only the latter combination which lessens the commercial value of the fuel. By boiling the powdered coal with a solution of carbonate of soda, the lime composed is clecomposed, and by washing the sulphuric acid may be removed; in the residue is contained the sulphur, combined with iron, which is estimated by any of the methods familiar to chemists. Mr. E. C. C. Stanford next gave the results of Some Preliminary Experiments on the Retention of Oranic Nitrogen by Charcoal; these he intends to prosecute still further, and to communicate his observations to the next meeting at Brighton. Mr. I. Smyth gave' an account of Some Improvements in Chlorimetry. In his opinion the use of the milky solution of bleaching powder as employed in the usual methods of chlorimetry is unsatisfactory, and he accordingly recommends that the chloride of lime be decomposed by a solution of carbonate of soda and filtered from the precipitated carbonate of lime when the amount of available chlorine may be determined in the filtrate by any of the usual methods. Professor Delffs, of Hiedelberg, exhibited some splendid Crystats of Sorbln. This body was discovered nearly twenty years ago by Pelouze, but hitherto nobody has succeeded in preparing it from the source indicated by the distinguished French chemist. Dr. Delffs attributed the want of success to the fact that it was usual to combine the preparation of malic acid with that of sorbin, and he showed that it is only when the production of the former substance is dispensed with that sorbin is obtained. By strictly following the method given by Pelouze, Dr. Delffs obtained a large quantity of fine crystals of Sorbin, but on searching for malic acid in the residue, he found that not a trace was present. He attributes its absence to its combination with the radical of alcohol (the malic acid being contained in the alcoholic extract of the berries of Sorbus Aucuparia, the source of the body), whereby malate of ethyl is formed, while by assimulating two atoms of water is converted into sorbin. It would appear therefore that no sorbin is contained ready formed in the fruit of Sorbus Aucuparia.

Dr. Emerson Reynolds gave an account of his experiments On the Action of Aldehyde on Sulpho-and Oxygen Ureas, and exhibited a variety of preparations of these compounds.

Mr. W. Chandler Roberts, chemist of the Mint, read a short paper On the Molecular Arrangement of the Alloy employed for the British. Silver Coinage. The paper proved that the homogeneous character of the alloy of silver and copper is destroyed by the cooling of the molten mass, the silver being concentrated in the centre.

Dr. Moffatt read a paper on Ozonometry, in which he stated that ozone test papers do not become permanently coloured in the neighbourhood of cesspools, and that the brown coloration when found is removed by the products of putrefaction. He also stated that light, the humidity of the atmosphere, and the direction of the wind, influence the colouring of the test paper, moisture with heat accelerating chemical action, while strong wind causes a great quantity of ozone to impinge upon the test paper in a given time. To counteract the effects of these, he recommended the test paper to be lkept in a box. He next described a tube ozonometer which he had had in use, and gave results obtained by an aspirator ozonometer, and concluded by stating that the results obtained by the aspirator ozonometer were not satisfactory.

\section{SECTION C}

On the Progress of the Geological Survey in Scotland, by Prof. Geikie.

When the British Association last met in Scotland, I had the honour of bringing before this Section a report upon the progress of the Geological Survey, from the time of its commencement here in 1854 by Professor Ramsay, under the direction of the late Sir Henry De la Beche, up to the year 1867 , under the supervision of the present Director, Sir Roderick Murchison. During the four years which have since elapsed, considerable advance has been made in the survey of the southern half of Scotiand, and I propose now, with the sanction of Sir Roderick, to present to you a brief outline of what has been clone, and of the present state of the Survey.

At the time of my previous report rather more than 3,000 square miles had been surveyed. Since then we have completed 2,700 square miles additional, making a total area of nearly 6,000 square miles, Of this area 3 , I 75 square miles have been published on the one-inch scale, and three sheets, representing in all 632 square miles, are now in course of being engraved. The whole country is surveyed upon the Ordnance Maps on the scale of six inches to a mile, and from these field-maps the work is reduced to the one-inch scale, which is the scale adopted for the general Geological Map of the country. In addition to that general map, however, maps on the larger or six-inch are published of all mineral tracts. In this way five sheets of the six-inch maps have now been published, embracing the whole of the coalfields of Fife, Haddingtonshire, and Edinburghshire, with a large portion of the coal-fields of Ianarkshire, Renfrewshire, Ayrshire, and Dumfriesshire.

The area over which the field-work of the Survey has extended lies between the mouths of the Firths of Tay, Forth, Clycle, and Solway, eastwards to the borders of Roxburghshire and the mouth of the Tweed. It includes the counties of Fife, Kinross, the Lothians, Lanark, Renfrew, Peebles, Ayr, Wigton, Kirkcudbright, Dumfries, and Selkirk, with parts of Stirling, Dumbarton, and Perth.

Of the geological formations examined, the Lower Silurian rocks of the southern uplands cover a considerable space upon the published maps. Until three years ago the mapping of these rocks continued to be most unsatisfactory, owing to the want of any continuous recognisable section from which the orcler of succession among the strata could be ascertained, and to the great scarcity of organic remains. Our more recent work among the Leadhills, however, has at last given us the means of unravelling, as we hope, the physical structure and stratigraphical relations of the uplands of the south of Scotland. The rocks there are capable of division into several well-marked groups of strata, characterised by distinct assemblages of fossils. We have a lower or Llandeilo series with a suite of graptolites, and forming probably an upper part of the Moffat group, and a higher or Caradoc set of beds, with a considerable assemblage of distinctive fossils. This higher group we believe to be on the same general horizon as the limestones of Wrae and Kilbucho in Peeblesshire.

The Lower Old Red Sandstone 'has now been mapped completely over the whole of jts extent between Edinburgh and the south of Ayrshire. Fossils have only been met with at one locality in the latter county, where Cephalaspis occurs. The most characteristic feature of the formation is the enormous development of its interbedded volcanic rocks. Between Edinburgh and Lanarkshire, also, there occurs in this formation a local but violent unconformability, connected probably with some phase of the contemporaneous volcanic activity of the region.

Most of the detailed work of the Survey has lain upon Carboniferous rocks. In the lowest formations of this system, known as the Calciferous Sandstones, the Survey has now been able to trace a twofold division completely across the country, from sea to sea, viz. a lower group of red sandstones, and a higher group of white sandstones, green, grey, and dark shales, cement-stones, limestones, and occasional coal-seams. All these strata lie beneath the true Carboniferous Limestone. They are becoming daily more important from their containing in some places highly bituminous shales, from which paraffin oil can be made." The Carboniferous Limestone series, with its valuable coals and ironstones, has been mapped, and in great part published, for the eastern and south-western coal-fields, and this is also the case with the Coal-measures. Much addi- 
tional information has been obtained regarding the development of volcanic action in central Scotland during the Carboniferous period.

The Permian basins of Ayrshire and Thomhill have been surveyed and in great part published. Much fresh light has in the course of this Survey been thrown on the interesting Permian volcanoes of the south-west of Scotland.

Attention has been continuously given to the superficial accumulations. These are now mapped in as great detail as the rocks underneath, and plans are being prepared with the view to an issue of maps of the surface geology.

By a recent order of the Director-General, each one-inch map is now accompanied at the time of its publication, or as soon thereafter as possible, with an explanatory pamphlet, in which the form of the ground, geological formations, fossils, rocks, faults, and economic minerals, are briefly described, and such further information given as seems necessary for the proper elucidation of the map. These pamphlets are sold at an uniform price of $3 d$. Detailed. vertical sections are published for each coal-field. For the construction of these sections, records of boting operations are procured and recorded in the register-books of the Survey. Since 1867 more than 312,200 feet of such borings have in this way been entered in our books. Sheets of horizontal sections on a large scale are likewise issued. to form, with the maps and explanations, a compendium of the geological structure of each large district.

Another feature of the work of the Survey is the collection of specimens of the rocks and fossils of each tract of country as it is surveyed. Since my previous report to this Section of the British Association, we have collected I, o I specimens of rocks, and 7,500 fossils. These are named and exhibited, as far as the present accommodation will permit, in the Museum of Science and Art at Edinburgh.

The work of the Geological Survey is carried on, as I have said, minder the guidance of its Director-General, Sir Roderick Murchison, a name which has long been a household word at the mectings of the British Association, and one to which $I$ am sure you will permit me to make on this occasion more than a passing reference. While the Survey advances, as I have shown, steadily over the face of the country, uniravelling piece by piece the complicated details of its geological structure, to Sir Roderick belongs the rare merit of having himself led the way, by sketching for us, boldly and clearly, the relations of the kingdom. Much must undoubtedly remain for future investigation, but his outline of the grand essential features of Highland geology will ever remain as a monument of his powers of close yet rapid observation and sagacious inference. At one time I had hoped that the Chair of this Section might be filled by him, and that we should be permitted to listen anew to his expositions of the rocks of his native country. There is no one among us who does not regret the absence of the familiar face and voice of the veteran of Siluria. We meet once more on Scottish ground, and for the first time we have not here with us the man who has laid a deeper, broader impress on Scottish geology than any other geologist either of past generations or of this. There is, however, on the present occasion, a special cause for regret. Only within the last few months he founded a Chair of Geology in the University within whose walls we are now assembled-the first and only chair of the kind in Scotland. It would have been a fitting and grateful duty on the part of the University to welcome one of its most distinguished benefactors. I am well aware, indeed, that this Section-room is no place for the obtrusion of personal sentiments; yet I would fain be allowed to add in conclusion an expression of my own deep regret at the recent iliness and consequent absence of one to whom, over and above the admiration which we all feel for his life-long labours and his personal character, many years of friendly intercourse have bound me by the closest ties of affection.

\section{SECTION D.}

\section{BIOLOGY}

Opening Adpress by the President, Professor Allen THOMSON

IN now opening the meetings of the Biological Section, it is my first duty to express my deep sense of the honour which has been conferred on $\mathrm{m}$ e in appointing me to preside over its deliberations. I trust that my grateful acceptance of the office will not appear to be an assumption on my part of more than a partial connection with the very wide field of science included under the term Biology.

I would gladly have embraced the opportunity now afforded me of conforming to a custom which has of late become almost the rule with presidents of sections --viz., that of bringing under your review the more valuable discoveries with which our science has been enriched in recent times, were it not that the subjects which I might have been disposed to select would require an amount of detail in each which would necessarily limit greatly their number, and that any attempt to overtake the whole range of this wide-spread department of science would be equally pre. sumptuous and futile on the part of one whose attention has been restricted mainly to one of its divisions. I am further embarrassed in the choice of topics for general remark by the circumstance that many of those upon which $I$ might have ventured to address you have been most ably treated of by my predecessors; as for example, in the sectional addresses of Dr. Acland, Dr. Sharpey, Mr. Berkeley, Dr. Humphry, and Dr. Rolleston, as well as in the presiclential addresses of Dr. Hooker and Prof. Huxley. I must content myself therefore with endeavouring to convey to you some of the ideas which arise in my mind in looking back from the present upon the state of Biological science at the time when, forty years since, the meetings of the British Association com. menced-a period which I am tempted to particularise from its happening to coincide very nearly with that at which I began my career as a public teacher in one of the departments of biology in this city. In the few remarks which I shall make, it will be my object to show the prodigious advance which has taken place, not only in the knowledge of onr subject as a whole, but also in the ascertained relation of its parts to each other, and in the place which biological knowledge has gained in the estimation of the educated part of the community, and the consequent increase in the freedom with which the search after truth is now asserted in this as in other departments of science. And first, in connection with the distribution of the various subjects which are included under this section, I may remark that the general title under which the whole Section I) has met since 1866 , viz., Biology, seems to be advantageous both from its convenience, and as tending to promote the great con. solidation of our science, and a juster appreciation of the relation of its several parts. It may be that, looking merely to the derivation of the term, it is strictly more nearly synonymous with Physiology in the sense in. which that word has been for a long time employed, and therefore designating the science of life, rather than the description of the living beings in which it is manifested. But until a better or more comprehensive term be found, we may accept that of Biology under the general definition of "the science of life and of living beings," or as comprehending the history of the whole range of organic nature-vegetable as well as animal. The propriety of the adoption of such a general term is further shown by a glance at the changes which the titles and distribution of the subordinate departments of this section have undergone during the period of the existence of the Association.

During the first four years of this period the Section met under the combined designation of Zoology and.Botany, Physiology and Anatomy-words sufficiently clearly indicating the scope of i's subjects of investigation. In the next ten years a connection with Medicine was recognised by the establishment of a sub-section or department of Medical Science, in which, however, scientific anatomy and physiology formed the most prominent topics, though not to the exclusion of more strictly medical and surgical, or professional, subjects. Daring the next decade, or from the year 1845 to 1854 , we find along with Zoology and Botany a sub-section of Physiology, and in several years of the same time along with the latter a separate department of E!huology. In the eleven years which extended from 1855 to 1865 , the branch of Ethnology was associated with Geography in Section $F$. More recently, or since the arrangement which was commenced in 1866 , the section Biology has included, with some slight variation, the whole of its subjects in three departments. Under one of these are brought all investigations in Anatomy and Physiology of a general kind, thus embracing the whole range of these sciences when without special application. A second of these departments has been occupied with the extensive subjects of Botany and Zoology; while the third has been devoted to the subject of Anthropology, in which all researches having a special reference to the structure and functions or life-history of man have been received and dis. cussed. Such $I$ understand to be the arrangement under which we shall meet on this occasion. At the conclusion of my re. 
marks, therefore, the department of Anatomy and Physiology will remain with me in this room; while that of Zoology and Botany, on the one hand, and of Anthropology on the other, will adjourn to the apartments which have been provided for them respectively.

\section{Anthropology}

With regard to the position of Anthropology, as including Ethnology, and comprehending the whole natural history of man, there may be still some differences of opinion, according to the point of view from which its phenomena are regarded: as by some they may be viewed chiefly in relation to the bodily structure and functions of individuals or numbers of men; or as by others they may be considered more directly with reference to their national character and history, and the affinities of languages and customs; or by a third set of inquirers, as bearing more inmediately upon the origin of man and his relation to animals. As the first and third of these sets of topics entirely belong to Biology, and as those parts of the second set which do not properly fall under that branch may with propriety find a place under Geography or Statistics, I feel inclined to adhere to the distinct recognition of a department of Anthropology, in its present form; and I think that the suitableness of this arrangement is apparent, from the nature and number of the appropriate reports and communications which have been received under the last distribution of the subjects.

\section{Condition of Biological Research}

The beneficial influence of the British Association in promoting biological research is shown by the fact that the number of the communications to the sections received annually has been nearly doubled in the course of the last twenty years, and this influence has doubtless been materially assisted by the contributions in money made by the Association in aid of various biological investigations; for it appears that out of the whole sum of nearly $34,500 \%$. contributed by the Association to the promotion of scientific research, about 2,80ol. has been devoted to biological purposes, to which it would be fair to add a part at least of the grants for Palzeontological researches, many of which must be acknowledged to stand in close relation to Biology.

The enormous extent of knowledge and research in the various departments of Biology has become a serious impediment to its more complete study, and leads to the danger of confined views on the part of those whose attention, from necessity or taste, is too exclusively directed to the details of one department, or even, as often happens, to a subdivision of it. It would seem, indeed, as if our predecessors in the last generation possessed this superior advantage in the then existing narrow boundaries of knowledge, that it was possible for them to overtake the contemplation of a wider field, and to follow out researches in a greater number of the sciences. To such combinations of varied knowledge, united with their transcendent powers of sound generalisation and accurate observation, must be ascribed the wide-spread and enduring influence of the works of such men as Haller, Limnzus, and Cuvier, Von Baer, and Joannes Miiller. There are doubtless brilliant instances in our own time of men endowed with similar powers; but the difficulty of bringing these powers into effectual operation in a wide range is now so great, that, while the amount of research in special biological subjects is enormous, it must be reserved for comparatively few to be the anthors of great systems, or of enduring broad and general views which embrace the whole range of biological scicnce. It is incumbent, therefore, on all those who are desirous of promoting the advance of biological knowledge, to combat the confined views which are apt to be engendered by the too great restriction of study to one departrunt. However much subdivision of labour may now be necessary in thic sriginal investigation and elaboration of new facts in our science (and the necessity for such subdivision will necessarily increase as knowledge extends), there must be secured at first, by a wider study of the general principles and some of the details of collateral branches of knowledge, that power of justly comparing and correlating facts which will mature the judgment and exclude partial views. To refer only to one bright example; I may say that it can scarcely be doubted that it is the unequalled variety and extent of knowledge, combined with the faculty of bringing the most varied facts together in new combinations, which has enabled Mr. Darwin (whatever may be thought otherwise of his system) to give the greatest impulse which has been felt in our own times to the progress of biological views and thought ; and it is most satisfactory to observe the effect which this infuence is already producing on the scientific mind of this country, in opposing the tendency perceptible in recent times to the too restricted stucly of special departments of natural history. I need scarcely remind you that for the proper investigation and judgment of problems in physiology, a full knowledge of anatomy in general, and much of comparative anatomy, of histology and embryology, of organic chemistry and of physics, is indispensable as a preliminary to all successful physiological observation and experiment. The anatomist, again, who would profess to describe rationally and correctly the structure of the human body, must have acquired a knowledge of the principles of morploology derived from the study of comparative anatomy and development, and he must have mastered the intricacies of histological research. The comparative anatomist must be an accomplished embryologist in the whole range of the animal kingdom, or in any single division of it which he professes to cultivate. The zoologist and the botanist must equally found their descriptions and systematic distinctions on morphological, histological, and embryological data. And thus the whole of these departments of biological science are so interwoven and united that the scientific investigation of no one can now be regarded as altogether separate from that of the others. It has been the work of the last forty years to bring that intimate connection of the biological sciences more and more fully into prominent view, and to infuse its spirit into all scientific investigation. But while in all the clepartments of Biology prodigions advance has been made, there are two more especially which merit particular mention, as having almost taken their origin within the period I now refer to, as having made the most rapid progress in themselves, and as having influenced most powerfully and widely the progress of discovery, and the views of biologists in other departments - I mean histology and embryology.

\section{Histology}

I need scarcely remind those present that it was only within a few years before the foundation of the British Association that the suggestions of Lister in regard to the construction of achromatic lenses brought the compound microscope into such a state of improvement as caused it to be restored, as I might say, to the place which the more imperfect instrument had lost in the previous century. The result of this restoration became apparent in the foundation of a new era in the knowledge of the minute characters of textural structure, under thie joint gridance of Robert Brown and Ehrenberg, with contributions from many other observers, so as at last to have entitled this branch of inquiry to its designation, by Prof. Huxley, of the "exhaustive investigation of structural elements." All who hear me are fully aware of the influence which, from 1839 onwards, the researches of Schwann and Schleiden exerted on the progress of Histology and the views of anatomists and physiologists as to the structure and development of the textures both of plants and animals, and the prodigious increase which followed in varied microscopic observations. It is not for me here even to allude to the steps of that rapid progress by which a new branch of anatomical science has been created; nor can I venture to enter upon any of the interesting questions presented by this department of microscopic anatomy; nor fattempt to discuss any of those difficult problems possessing so much interest at the present moment, such as the nature of the organised cell, or the properties of protoplasm. I would only remark that it is now very generally admitted that the cell wall (as Schwann indeed himself pointed out is not a constant constituent of the ceil, nor a source of new production, though still capable of considerable structural change after the time of its first formation. The nuclets has also lost some of the importance attached to it by Schwrann and his earlier followers, as an essential constituent of the cell, while the protoplasm of the cell remains in undisputed possession of the field as the more immediate seat of the phenomena of growth and organisation, and of the contractile property which forms so remarkable a feature of their substance. I cordially agree with much of what Prof. Huxley has written on this subject in 1853 and 1869 . The term "physical basis of life" may perhaps be in some respect objectionable, but I look upon the recognition of protoplasm which he has enforced, as a most important step in the recent progress of histology; adopting this general term to indicate that part of the tissue of plants and animals which is the constant seat of the growing and moving phenomena; but not implying identity of nature and properties in all the variety of circumstance in which this substance may occur. To Haeckel the fuller history of protoplasm in its lowest forms is due. To Dr. Beale we owe the minutest investigation of the properties by the use of magnifying powers beyond any that had previously 
been known, and the successful employment of reagents which appear to mark out its distinction from the other elements of the textures. I may remark, however, in passing, that I am inclined to regard contractile protoplasm, whether vegetable or animal, as in no instance entirely amorphous or homogeneous, but rather as always presenting some minute molecular structure which distinguishes it from parts of glassy clearness. Admitting that the form it assumes is not necessarily that of a regular cell, and may be various and irregular in a few exceptional instances, I am not on that account disposed to give up definite structure as one of the universal characteristics of organisation in living bodies. I would also suggest that the terms formative and nonformative, or some such other, would "be preferable to those of "living and dead," employed by Di: Beale, to distinguish the protoplasm from the cell-wall or its derivatives, as the latter terms are liable to introduce confusion.

\section{Embryology.}

To the discoveries in embryology and development I might have been tempted to refer more at large, as being those which have had, of all modem research, the greatest effect in extending and modifying biological views, but I am wamed from entering upon a subject in which I might trepass too much on your patience. The merits of Wolff as the great furst pioneer in the accurate observation of the phenomena of development were clearly pointed out by Prof. Huxley in his presidential address of last year. Under the influence of Döllinger's teaching, Pander, and afterwards Purkinge, Von Baer, and Rathke, established the foundations of the modern history of embryology. It was only in the year 1827 that the ovum of mammals was discovered by Von Baer; the segmentation of the yelk, first observed by Prevost and Dumas in the frog's ovum in 1824 , was ascerained to be general in succeeding years, so that the whole of the interesting and important additions which have followed, and have nade the history of embryological development a complete science, have been included within the eventful period of the life of this Association. I need not say how distinguished the Germans have been by their contributions to the history of animal development. The names of Valentin, R. Wagner, Bischorf, Reichert, Kölliker, and Remak are sufficient to indicate the most important of the earlier steps in recent progress, withont attempting to enumerate a host of others who have assisted in the great work this founded. I am aware that the mere name of development suggests to some ideas of a disturbing kind as being associated with the theory of evolution recently promulgated. To one accustomed during the whole of his career to trace the steps by which every living being, including man himself, passes from the condition of an almost imperceptible germ, through a long series of changes of form and structure into their perfect state, the name of development is suggestive rather of that which seems to be the common history of all living beings; and it is not wonderful therefore that such a one should regard with approval the more extended view which supposes a process of development to belong to the whole of nature. How far that principle may be carried, to what point the origin of man or any animal can by facts or reasoning be traced in the long unchronicled history of the world, and whether living beings may arise independently of parents or germs of previously existing organisms, or may spring from the direct combination of the elements of dead matter, are questions still to be solved, and upon which we may expect this section to guide the hesitating opinion of the time. I cannot better express the state of opinion in which I find myself in regard to the last of these problems than by quoting the words of Professor Huxley from his address of last year, p. lxxxiii.:- -

"But though I cannot express this conviction of mine too strongly (viz., that the evidence of the most careful experiments is opposed to the occurrence of spontaneous generation), I must carefully guard myself against the supposition that $I$ intend to suggest that ${ }^{5}$ no such thing as abiogenesis ever has taken place in the past, or ever will talie place in the future. With organic chemistry, molecular physics, and physiology yet in their infancy, and every day making prodigious strides, I think it would be the height of presumption for any man to say that the conditions under which matter assumes the properties we call 'vital,' may not some clay be artificially brought together. And again, if it were given me to look beyond the abyss of geologically recorded time, to the still more remote period when the earth was passing through physical and chemical conditions which it can no more see again than a man can recall his infancy, I should expect to be a witness of the evolution of living protoplasm from not living matter." I will quote further a few wise words from the dis- course to which many of you must have listened last evening with acimiration. Sir William Thomson said-_" The essence of science, as is well illustrated by astronomy and cosmical physics, consists in inferring antecedent conditions, and anticipating future evolutions, from phenomena which have actually come under observation. In biology, the difficulties of successfully acting up to this ideal are prodigious. Our code of biological law is an expression of our ignorance as well as of our knowledge." And again, "Search for spontaneous generation out of inorganic materials; let any one not satisfied with the purely negative testimony, of which we have now so much against it, throw himself into the inquiry. Such investigations as those of Pasteur, Pouchet, and Bastian are among the most interesting and momentous in the whole range of natural history; and their results, whether positive or negative, must richly reward the most careful and laborious experimenting."

\section{Organic Chemistry and Vital Force}

The consideration of the finest discoverable structures of the organised parts of living bodies is intimately bound up with that of their chemical composition and properties. The progress which has been made in organic chemistry belorgs not only to the knowledge of the composition of the constituents of organiged bodies, but also to the manner in which that composition is chemically viewed. Its peculiar feature, especially as related to biological investigation, consists in the results of the introduction of the synthetic method of research, which has enabled the chemist to imitate or to form artificially a greater and greater number of the organic compounds. In 1828 the first of these substances was formed by Wöhler, by a synthetic process, as cyanate of ammonia, or urea. But still, at that time, though a few no doubt entertained juster views, the opinion generally pre. vailed among chemists and physiologists that there was some great and fundamental difference in the chemical phenomena and laws of organic and inorganic nature. Now, however, this supposed barrier has been in a great mensure broken down and removed, and chemists, with almost one accord, regard the laws of combination of the elements as essentially the same in both classes of bodies, whatever differences may exist in actual composition, or in the reactions of organic bodies in the more complex and often obscure conditions of vitality, as compared with the simpler, and, on the whole, better known phenomena of a chemical nature observed in the mineral kingdom. Thus, by the synthetic method, there have been formed among the simpler organic compounds a great number of alcohols, hydrocarbons, and fatty acids. But the most remarkable example of the synthetic formation of an organic compound is that of the alkaloid conia, as recently obtained by Hugo Schiff by certain reactions from butyric aldehyde, itself an artificial product. The substance so formed, and its compounds, possess all the properties of the natural conia-chemical, physical, and physiological-being equally poisonous with it. The colouring-matter of madder, of alizarine, is another organic compound which has been formed by artificial processes. It is true that the organised or containing solicl, either of vegetable or animal bodies, has not as yet yielded to the ingenuity of chemical artifice; nor, incleed, is the actual composition of one of the most important of these, albumen and its allies, fully known. But as chemists have only recently begum to discover the track by which they may be led to the synthesis of organic compounds, it is warrantable to hope that ere long cellulose and lignine may be formed; and, great as the difficulties with regard to the albumenoid compounds may at present appear, the synthetic formation of these is by no means to be clespaired of, but, on the contrary, may with confidence be expected to crown their efforts. From all recent research, therefore, it appears to result that the general nature of the properties belonging to the products of animal and vegetable life, can no longer be regarded as different from those of minerals, in so far at least as they are the subject of chemical and physical investigation. The union of elements and their separation, whether occurring in an animal, a vegetable, or a mineral body, must be looked upon as dependent on innate powers or properties belonging to the elements themselves; and the phenomena of change of composition of or. ganic bodies occurring in the living state are not the less chemical becatise they are different from those observed in inorganic nature. All chemical actions are liable to vary according to the conditions in which they occur, and many instances night be adducerl of most remarkable variations of this kind, observed in the chemistry of dead bodies from very slight changes of electrical, calorific, mechanical, and other conditions. But because the conditions of action or change are infinitely more complex and far 
less known in living bodies, it is not nececsary to look upon the phenomena as essentially of a different kind, to have recourse to the hypothesis of vital affinities, and still less to shelter ourselves under the slim curtain of ignorance implied in the explanation of the most varied chemical changes by the infuence of a vital principle.

\section{Zoology and Botany}

On the subjects of zoological and botanical classification and anthropology, it would be out of place for me now to make any observations at length. I will only remark, in regard to the first, that the period under review has witnessed a very great modification in the aspect in which the affinities of the bodies belonging to these two great kingdoms of nature are viewed by naturalists, and the principles on which groups of bodies of eacli are associated together in systematic classification; for; in the first place, the older view has been abandoned that the complication of structure rises in a continually increasing and continuous gradation from one kingdom to the other, or extends in one line, as it were, from group to group in either of the kingdoms separately. Evolution into a gradually increasing complexity of structure and function no doubt exists in both, so that types or general plans of formation must be acknowledged to pervade, presenting typical resemblances of construction of the deepest interest; but in the progress of morpbological research, it has become more and more apparent that the different groups form radiations, which touch one another at certain points of greatest resemblance, rather than one continuous line, or a number of lines which partially pass each other. The simpler bodies of the two kingdoms of nature exhibit a gradually increasing resemblance to each other, until at last the differences betweein semblance to each other, until at last the differences between the properties become almost indistinguishable, as in the remarkable Protista of Haeckel and others. I fully agree, however, able Protista of Haeckel and others. Thomson in his recent extraorinary lecture, that it is not necessary on this account to recosnise an intermedia:e kingdom of nature. Each kingdom presents, as it were, a radiating expansion into groups for itself, so that the relations of the two kingdons might be represented by the divergence of lines spreading in two different directions from a common point. Recent observations on the chorda dorsalis (or supposed notochord) of some Ascidians tend to revive the discussion at one time prevalent, but long in abeyance, as to the possibility of tracing a homology between the vertebrate and invertebrate animals; and, should this correspondence be confirmed and extended, it may be expected to modify greatly our present views of zoological affinities and classification. It will also be an additional proof of the importance of minute and embryological research in systematic determinations. The recognition of homological resemblance of animals, to which in this country the researches of Owen and Huxley have contributed so largely, form one of the most interesting subjects of contemplation in the study of comparative anatomy and zoology in our time; but I must refrain from touching on so seductive and difficult a subject.

\section{Natural Science in Schocls}

There is another topic to which I can refer with pleasure as connected with the cultivation of biological knowledge in this country, and that is the introcluction of instruction in natural science into the system of education of our schnols. As to the feasibility of this in the primary schools, I believe most of those who are intimately acquainted with their management have expressed their decidedly favourable opinion -it being found that a portion of the time now allotted to the three great requisites of a primary education might with advantage be set apart, for the purpose of instructing the pupils in subjects of common interest, calculated to awaken in their minds a desire for knowledge of the various objects presented by the field of nature around them. As to the benefit which may result from this measure to the persons so instructed, it is scarcely necessary for me to say anything in this place. It is so obvious that any varied knowledge, how. ever ensily acquired or elementary, which tends to enlarge the ever ensily acquired or elementary, which tencls to enlarge the range of obsecipients from grosser infuences, and may even supply information which may prove useful in social economy and in the occupations of labour. Nor need I point ont how much more extended the advantages of such instruction may prove if introduced into the system of cur secondary schools, and prove if introduced into the syan heretofore with the too exclusively literary and philosophical study which has so long prevailed in the approved British education. Without disparagement to those modes of study as in themselves necessary and useful, and excellent means of disciplining the mind to learning, I catanot but hold it as curtain that the mind which is entirely without scientific cultivation is but half prepared for the common purpases of modern life, and is en:irely unculuilifed for forming a judgment on some of the most difficult and yet most common and important questions of the day, affecting the interests of the whole community. I refer with pleasure to the published Essay of Dr. Lankester cn this subject, and to the arguments addressed two days ago by $\mathrm{Dr}$. Bennett to the medical graduates of the University, in favour of the establishment of physiology as a subject of general education in this comntry, with reference to sanitary conditions. It is gratifying, therefore, to perceive that the suggestions made some years ago in regard to this subject by the British Association, through its committee, have already borne good fruit, and that the attention of those who presicle over education in this comtry, as well as of the public themselves, is more earnestiy clirected to the object of securing for the lowe t as well as the highest classes of the community that wholesome combination of knowiedge derived from education, which will duly cultivate all the faculties of the mind, and thus fit a greater and greater number for applying themselves with increased ability and knowledge to the purposes of their living and its improved condition. If the law of the Survival of the Fittest be applicab!e to the mental as well as to the physical improvement of our race (and who can doubt that in some measure it must be so), we are bound by motives of interest and duty to secure for all classes of the people that lind of edlucation which will lead to the development of the highest and most varied mental power. And no one who has been olbservant of the recent progress of the useful arts, and its influence upon the moral, social, and political condition of our population, can doubt that that education must include instruction in the phenomena of external nattre, including, more especially, the laws and conditions of life and health; and that it ought to be, at the same time, such as will adapt the mind to the ready acquisition and just comprehension of varied knowledge. It is obvious, too, that while this more immediately useful or beneficial effect on the common mind may be produced by the diffusion of natural knowledge amnng the people, biological science will share in the gain accruing to all branches of natural science, by the greater favour which will be accorded to its cultivators, and ihe increased freedom from prejudice with which their statements are received and considered by learned as well as by unscientific persons.

\section{Spiritualism}

I cannot conclucle these observations without adverting to one aspect in which it might be thought that the appreciation of biolugical science has taken a retrograrle rather than an advanced position. In this, I do not mean to refer to the special cultivators of Biolosy in its scientific acceptation, but to the fact that there appears to have taken place of late a considerable increase in the number of persons who believe, or who imagine that they believe, in the class of phenomena which are now called spiritual; but which have been known since the exhibitions of Mesmer, and, indeed, long before his time, inder the most varied forms, as liable to occur in persons of an imaginative turn of mind and peculiar nervous susceptibility. It is still more to be regretted that many persons devote a large share of their time to the practice-for it cloes not deserve the name of study or investigationof the alleged phenomena, and that a few men of acknowledged reputation in some departments of science have lent their names, and surrendered their judgment, to the countenance and attempted authentication of the foolish dreams of the and attempted authentication, and similar chimerical hypo theses. The natural tendency to a belief in the marvellous is sufficient to explain the ready acceptance of such views by the ignorant; and it is not improbable that a higher species of similar credulity may frequently act with persons of species of similar credulity may frequently act with persons greater cultivation, should their scientific information and train ing have been of a partial kind. It must be admitted, further, that extremely curions and rare, and to those who are not acquainted with nervous phenomena, apparently marvellous phenomena, present themselves in peculiar states of the nervous phenomena, present themsetves may be induced through the mind, system-sone of which states may be induced throure and are greatly exagrerated by frequent repetition. But making. the fullest exaggerated by for these conditions, it is still surprising that allowance for all these conctions, otherwise appearing to be within the bounds of sanity, shonld entertain a confirmed belief in the possibility of pheno. mena, which, while they are at variance with the best established 
physical laws, have never been brought under proof by the evidences of the senses, and are opposed to the dictates of sound judgment. It is so far satisfactory in the interests of true biological science that no man of note can be named from the long list of thoroughly well-informed anatomists and physiologists, who has not treated the belief in the separate existence of powers of animal magnetism and spiritualism as wild speculations, devoid of all foundation in the carefully tested observation of facts. It has been the habit of the votaries of the systems to which I have referred to assert that scientific men have neglected or declined to investigate the phenomena with attention and candour; but nothing can be farther from the truth than this statement. Not to mention the admirable reports of the early French academicians, giving the account of the negative result of an examination of the earlier mesmeric phenomena by men in every way qualified to pronounce judgment on their nature, I am aware that from time to time men of eminence; and fully competent, by their knowledge of biological phenomena, and their skill and accuracy in conducting scientific investigation, have made the most patient and careful examination of the evidence placed before them by the professional believers and practitioners of so-called magnetic, phreno-magnetic, electro-biological, and spiritualistic phenomena; and the result has been uniformly the same in all cases, when they were permitted to secure conditions by which the reality of the phenomena, or the justice of their interpretation, could be tested-viz., either that the experiments signally failed to educe the results professed, or that the experimenters were detected in the most shameless and determined impostures. I have myself been fully convinced of this by repeated examinations. But were any guarantee required for the care, soundness, and efficiency of the judgment of men of science on these phenomena and views, I have only to mention, in the first place, the revered name of Faraday, and in the ncxt that of my life-long friend Dr. Sharpey, whose ability and candour none will dispute, and who, I am happy to think, is here among us, ready, from his past experience of such exhibitions, to bear his testimony against all classes of levitation, or the like, which may be the last wonder of the day among the mesmeric or spiritual pseudo-physiologists. The phenomena to which I have at present referred are in great part dependent upon natural principles of the human mind, placed, as it would appear, in dangerous alliance with certain tendencies of the nervous system. 'They ought not to be worked upon without the greatest caution, and they can only be fully understood by the accomplished physiologist who is also conversant with healthy and morbid psychology. The experience of the last hundred years tends to show that while there are always to be found persons peculiarly liable to exhibit the phenomena in question, there will also exist a certain number of minds prone to adopt a belief in the marvellous and striking in preference to that which is easily understood and patent to the senses; but it may be confidently expected that the diffusion of a fuller and more accurate knowledge of vital phenomena among the non-scientific classes of the community may lead to a juster appreciation of the phenomena in question, and a reduction of the number among them who are believers in scientific impossibilities.

\section{SECTION E, GEOGRAPHY}

Opening Address by the President, Col. H. Yule, C. B. THE first natural duty in circumstances like the present is to pay a tribute, however inadequate, to the memory of the eminent geographer whom we expected to fill this chair. The long list of his works has been rehearsed in so many of the notices that have honoured his memory, as well as in the address of the Vice-President of the Geographical Society, when presenting the medal which he had won by so many years of faith ful labour in the cause of Geography, that I need not now repeat them. Indeed, when contemplating the catalogue of such an amount of work achieved, an amateur geographer like myself stands abashed; but feels at the same time that his own limited experience and desultory studies serve at least to furnish him with some just scale by which to estimate the vast labours involved in the accomplishment of such a life's work as Dr. Keith Johnston's.

I shall in this address attempt no general view of the geographical desiderata of the time, and of recent geographical progress in discovery and literature throughout the world. Living habitually far from new books and meetings of societies, I am not sufficient for these things, nor, if I were, could I easily vary from the comprehensive epitome of the year's geography, which but two months ago was issued, though, as we know with sorrow, not delivered, by him who has been so long the Dean of the Faculty of Geographers in Britain, and whose name is identified throughout the Continent with English geography. Sir Roderick Murchison has desired me to take occasion to express his deep regret at his inability to be present at this meeting. It is, he said, one of the most painfully-felt disappointments that his illness has occasioned. For he had looked forward with strong interest to taking patt once more in a meeting of the Association at the chief city of his native country - with which city, I may remind you, he the other day bound his name and memory by strong and enduring ties in the foundation of a Chair of Geology in this University. Instead, then, of attempting a review which in my case would be crude, and therefore both dull and uninstructive, I propose to turn to one particular region of the old world with which my own studies have sometimes been concerned, and to say something of its characteristics, and of the progress of knowledge, as well as of present questions regarding it.

There are, however, one or two points on which I must first touch lightly. Of Livingstone, all that there is to tell has already been told to the world by Sir Roderick Murchison. We know the task that Livingstone had laid out for himself in dispersing the darkness that still hangs over some of the greatest fealures of Central African hydrography, by determining the ultimate course of the great body of drainage which he has followed northward from $12^{\circ}$ south latitude--whether towards the Congo and the Atlantic, or towards Baker's Lake and so to the Nile; as well as the kindred question of the discharge of Lake Tanganyika ; but of his progress in the solution of those questions we know nothing. I can but add that Sir Roderick himself has lost none of his confidence in the accomplishment of the task, and in the return of the great traveller at no distant period. That confidence of his has been so often before justified by the arrival of fresh news of Livingstone, however meagre, that we may well retain stro.g hope, even if it be not granted to all of us to rise from hope into confidence. We trust, then, that Livingstone will never have a place among the martyrs of geography.

One addition, however, has been made during the past year to that long list, in the name of the undaunted George Hayward, formerly a lieutenant in the 72nd Regiment, who had for some years resolutely devoted himself to geographical discovery. After having proved his powers in a journey to Yarkand and Kashghar, which obtained for him last year one of the medals of the Geographical Society, he had started again, with aid from that Society, to attempt an examination of the famous plateau of Pamir, hoping to succeed in crossing it, and to descend upon the Russian territory at Samarkand. In the Darkot Pass above Yas. sin, he was foully murdered by the emissaries of the chief of that district, Mir Wali by name. Public suspicion in India first turned upon the Maharajah of Kashmir, on whose alleged oppressions Hayward, in a private letter, had made severe remarks, which were rashly published by the editor of a local newspaper. The latest intelligence seems to exonerate the Maharajah, and to throw the guilt of complicity rather on the Mahomedan Chief of Chitral. If he be the guilty man, it may be difficult to punish him, so in. accessible is his position at present; for, to apply the old saw of the Campbells, "It is a far cry to Chitral." I may observe, however, that some sixteen or seventeen years ago, a similar murder took place on the persons of two poor French priests at the other extremity of India, and within the Thibetan boundary on the Upper Brahmapootra, and the apprehension of the crimi nal must have seemed almost as hopeless as in this case. Yet eventually he fell into the hands of our officers of the province of Assam, and paid the due penalty of his crime.

The geographical field on which, with your permission, I pro. pose to expatiate for a little, is that of India beyond the Ganges. $\mathrm{I}$ mean in the largest sense of the expression, and inclusive, at least, in some points of view, of the Indian Islands. India, in deed, in old times was a somewhat vague term, or at least it had always a vague as well as an exacter interpretation. In the latter, it had the same application that we give it now when we speak with precision; it meant that vast semi-peninsular region roughly limited by the valleys of the Indus and the Ganges, which embraces many nations and many tongues and many climates, but yet all pervaded by a certain almost intangible character, which gives it a kind of unity recognised by all. In its vaguer sense, India meant simply the Far East. The traces of such use still survive in such expressions as the East Indies or the Indian Archipelago. Though this vague and large application of the name probably arose only from the vagueness of knowledge, it coincides roughly with a fact, and that is the extraordinary expansion of Hindoo 
influence which can be traced in the vestiges of religion, manners, architecture, language, and nomenclature over nearly all the regions of the East to which the name has been applied. Another name has been applied to the continental part of this region-Indo-China. This, too, expresses the fact that on this area the influences of India and of China have interpenetrated. But the influence of China has, except on the eastern coast, been entirely political, and has not, like India, affected manners, arts, and religion.

The address concluded with a long and interesting account of the land trade which has been maintained for many centuries between Western China and the Valley of the Iriwadi.

\section{SECTION F.}

\section{ECONOMIC SCIENCE AND STAT'TSTICS}

OpeniNg ADDRESS BY THE PRESIDENT, LoRd NeAves

The greater part of this address deals with subjects beyond our scope; we may, however, make the following extracts :-

Economic science is sometimes spoken of as having a very modern date; but I think that this is an error. More or less the subject has entered into all the codes or systems of law that have been established from the earliest times. Alongside of political philosophy, which may be considered as peculiarly the science of government, great attention has always been bestowed upon matters which form an important part of political economy, or economic science-such as taxation, trade, commerce, wealth, and population. Those writers also who have presented us with ideal or imaginary states or Utopias are full of discussions and speculations of the same kind. The rival "Republics" of Plato and A ristotle afford abundant illustrations of this statement. It is peculiarly interesting to see this fact brought out so vividly in the admirable introduction to the "Republic" of Plato, prefred to that treatise in Prof. Jowett's translation of that great philosopher; and if we had a similar translation and exposition of Aristotle's kindred work, which $I$ think we might have from the hand of one of our own vice-presidents, to whom we owe so excellent an exposition of the "Ethics," we should see in a remarkable manner bow many of the most interesting questions of the present day were considered and dealt with by those wonderfil men according to the varying lights and tendencies which characterised their several minds. It is true that in more recent times a great advance has been made in economic science, and the chief feature and excellency of that change is the tendency to leave things as much as possible to their natural operation, and to the inherent laws of nature and society. It is to the credit of Scotland that she has produced the two greatest leaders in this altered movement-David Hume and Adam Smith-who are still high authorities on the whole subject, and whose principles have been made the basis of our recent legislation. The subject of Statistics is added to the title of this section as an auxiliary to the main subject of Economic Science.

The subjects to which statistics may be extended seem to be innumerable, and new ones are cropping up every day. In the pages of NATURE there lately appeared a letter of a somewhat curious kind, which may perhaps engage the attention of our fellow-associate member Mr. Tyler. The suggestion in that letter was that the degree of civilisation existing in any country is connected with the quantity of soap there consumed. The writer gave as a formula the equation of

$$
x=\frac{S}{P}
$$

$x$ being the amount of civilisation inquired for, $\mathrm{S}$ being the soap $x$ consumed, and $\mathrm{P}$ the population consuming it. So that the amount of civilisation depended on the proportion of $S$, the numerator, to $P$, the denominator. If $S$ is large in proportion to $\mathrm{P}$ then the civilisation is great, and vice versd. How the civilisation of Scotland in the olden times would come out according to this test I shall not inquire; but if there is any truth in the proposition, it gives additional relevancy and interest to the the proposition which is sometimes vulgarly put by some people to their friends as to how they are provided with that commodity. I have not get seen any tables framed upon this principle, but I have no doubt that the Registrar-General will keep it in view. An inquiry of a more serious nature, and indeed peculiarly important and impressive, is connected with one of the most remarkable phenomena in human nature-I mean the occasional appearance in the world of men of great genius. From time to time men have arisen whose mental powers have far transcended the ordinary average of human intellect, and who have thereby been enabled, within the space of a single life, and by the effort of a single mind, to give an impulse to science and discovery which they could not have received throngh long generations of average mediocrity. Whether this singular boon and blessing to mankind can be traced to any law is a natural but mysterious inquiry. Some persons have considered the production of exceptional genius as quite an insulated fact; and Savage Landor declared that no great man had ever a great son, unless Philip and Alexander of Macedon constituted an exception. Mr. Galton, however, in his interesting work on "Hereditary Genius," has endeavoured to prove that genius runs in families, or, at least, that men of genius have generally sprung from a stock where great mental power is conspicuous; and he adheres to the view commonly taken as to the importance of the maternal character and in. filuence in the formation of genius. I do not venture to give any opinion upon Mr. Galton's theory, but his book contains an important collection of facts bearing on the subject, and a great deal of very curious collateral speculation. Mr. Galton attributes great power in many ways to the principle of heredity, as it seems now to be called. He does not indeed go so far as the Irish statist, who, as mentioned by Sydney Smith, announced as a fact that sterility was oflen hereditary; but he states that comparative infertility is transmitted in families; and adduces as a remarkable example, a fact not generally known, if it be a fact, that in the case that frequently happens of Peers marrying heiresses, the family is apt to die out very soon, the heiress being naturaily, in the general case, an only child, and bequeath ing to her descendants a tendency to produce small families, who do not afford the usual chance of a numerous supply of descendants. Whatever may be said of some of his other opinions, I hesitate to concur with Mr. Galton in his proposition that as it is easy "to obtain by careful selection a breed of dogs or horses, gifted with peculiar powers of running, or of doing anything else, so it would be quite practicable to produce a highly-gifted race of men by judicious marriages during several consecutive generations." I doubt greatly the practicability of such a plan; and suspect there are some elements in human nature that would counteract it. Persons of proud family descent have often a horror of mesalliances; but I scarcely think it would be possible to inspire people of genius with the same esprit de corps or desire to wed with those on a par with them. Men of genius don't seem to me apt to fall in love with women as clever as themselves, and I rather suspect the tendency is to look for some difference of character, an instinct of which it is the object, or at least the result, to keep up the average of talent rather than to multiply the highest forms of mental power. At any rate we may here ask poor Polly's question, "Can love be controlled by advice?" and however we may in other respects agree with Horace's maxim, "Fortes creantur fortibus et bonis," I question whether a high mental stature could be maintained by coupling male and female genius together, or whether the experiment might not fail as signally as it is said sometimes to have done with Frederick. William's attempts to breed Grenadiers. I strenuously advise, however, that a marriage with a fool of either sex should be always considered as a mesalliance, and I would particularly warn the ladies against such a step, taken, sometimes it is said, in the hope that their sway may in that way be more easily maintained. A fool is as difficult to be governed as a mule, and the couplet, I believe, is strictly true, that says-

Wise men alone, who long for quiet lives Wise men alone are governed by their wives.

\section{SCIENTIFIC INTELLIGENCE FROM $A M E R I C A$ 은}

THE geological expedition under Prof. Hayden, at last advices, had reached Fort Hall, in Utah, on June $2 \mathrm{I}$, after a march from Ogden, during which much of interest was obtained by the party. The heat was very great, reaching from $95^{\circ}$ to $105^{\circ}$ in the shade during the day, with a difference of $25^{\circ}$ to $35^{\circ}$ between the wet and dry bulb thermometers. The party expected to pass Fort Ellis by the middle of July, on its. way to the basin of the Yellow Stone Lake, where it will probably spend the greater part of the season. Mr. Thomas Moran, of Philadelphia, and Mr. Bierstadt, were to join the expedition before long for the purpose of making sketches for paintings.-In the August number of the American Fournal of Science, will be found a con-

\footnotetext{
* Contributed by the Editor of Harper's Wefkly.
} 